\title{
Editorial
}

\section{Revised Guidelines to the Practice of Anaesthesia}

The Canadian Anaesthetists' Society has published the second edition of the guidelines to the practice of anaesthesia in Canada. The first edition, written in 1976 and published in 1981,' represented a milestone in the Society's history as it moved publicly to endorse a basic standard of patient care. The revision, now being distributed to all Society members, updates the previous document to reflect those advances in the specialty expected to improve the quality of anaesthetic service.

Elements of the revision deal with the method of operation of a hospital department, while others lend guidance to the dispersion of responsibility for anaesthetic and technical service between physicians, nursing, and administration. Basic monitors for all patients receiving any anaesthetic are detailed, including the constant attendance by the anaesthetist in the operating room. Appropriate electromechanical monitoring includes continuous demonstration of the electrocardiogram, inspired oxygen tension, and ventilator pressure, all to supplement regular observation of pulse, blood pressure, peripheral circulation, and respiratory adequacy. Newer technological advances, such as capnography and pulse oximetry, are recommended but not yet considered mandatory. Although the professional conduct advocated in the Guidelines is that which is seen to be reasonable, practical and readily obtainable, it is acknowledged that it is a minimum standard, to be exceeded at liberty as the situation dictates.

Why publish such a document at all? Surely all physicians already feel subject to excessive administrative influences, while their libcrty to practice as thcy see fit has been progressively eroded. The most obvious reason is the need to describe a standard for anaesthetic care in this country against which comparisons can be made. As individual physicians, and as departments, we can rest

\section{Dr. P.G. Duncan}

Past Chairman, Standards of Practice Committec, Canadian Anacsthetists' Society

Department of Anaesthesia, University Hospital, University of Saskatchewan, Saskatoon, Saskatchewan, S7N 0X0. assured that we are practicing good quality medicine only if we know what is being done elsewhere.

The published document presents what is current practice across the country, and it behooves each of us to meet or exceed this level of care. Patient satisfaction and safety should be improved, and the economic wager we all maintain in malpractice insurance will be defended There is no implied intent to standardize the specialty, a privilege not empowered to the Society, and definitely not sought. There is, however, hope that affirmative action to meet the Guidelines will enhance the respect accorded our specialty.

The publication of guidelines in medical care is not without precedent. Paediatricians have for years adbered to guidelines for immunizations, obstetricians to principles for breast feeding, while surgeons undertake rigorously standardized procedures to prevent sepsis. Public outcry in the wake of disasters has sensationalized the need for anaesthetists to incorporate certain safety principles into practice, often enforced by coroner's rulings or provincial Colleges of Physicians and Surgeons.

In the United States at least one insurance carrier ${ }^{2}$ (Mutual Insurance Company of Arizona) has imposed a $\$ 25,000$ deductible and threat of failure to renew the insurance if any anaesthesiologist is found negligent while not utilizing an ECG, a precordial stethoscope and blood pressure monitoring. The Harvard group of teaching hospitals has recently published ${ }^{3}$ what they consider to be minimal acceptable monitoring during andesthesia undoubtedly these will be referenced frequently as the "standard" in that country, in spite of the reservations as to their universal applicability." The ASA House of Delegates has similarly endorsed minimal standards for monitoring in the United States, the substance of which will soon appear in their publications.

Canadian anaesthetists have many other groups with expectations of our specialty, but without complete knowledge of the discipline. It is well that we, as anaesthetists, should determine for ourselves what is both reasonable and appropriate to our own clinical practice.

We acknowledge that not all is perfect with the pub- 
lication. The material represents a consensus from the anacsthetic community of this country - in the absence of published data there is no absolute "proof" of its validity. Practising according to the guidelines does not guarantee any designated patient outcome. A legal opinion has been obtained before publication, but the influence of the document on medical litigation will only become clear with time. The Society recognizes that the rapid pace of developments in our specialty dictates the need for an on-going process of revision to prevent early out-dating. Finally, it is probable that situations will occur rarely that prohibit application of the published guidelines - careful documentation in the patient's chart as to why an alternative standard was practiced would be prudent to limit future liability.

The Society commends the publication to all physicians practicing anaesthesia in Canada, and encourages compliance with its principles. Constructive comments about the contents are welcome as we move to future editions. If we are successful by its publication in focusing our individual and collective thoughts on the quality of our provided care we will do much to enrich our members" mission: to "watch carefully over those who sleep."

\section{Revision des directives relatives à l'exercice de l'anesthésie}

La Société Canadienne des Anesthésistes a publié la seconde édition des Lignes directrices de la pratique de l'anesthésie au Canada. La première édition, écrite en 1976 et publiée en $1981,{ }^{\prime}$ représentait alors un évène ment marquant dans l'histoire de la Sociêtế par l'appui publique d'une norme de base pour les soins du patient. La revision, actuellement distribuée à tous les membres de la Société met à jour le document précédent et réflète les progrès de la spécialité dans l'amélioration de la qualité des services anesthésiques.

Les éléments revus concernent les méthodes d'operation du département hospitalier et la description des normes de partage de responsabilité des services anesthésiques et techniques entre médecins, personnel infirmier et administrateurs. Les moniteurs de base pour tous les patients recevant de l'anesthésie sont détaillés et la présence constante de l'anesthésiste en salle d'opération est requise. La surveillance électronécanique appropriée in- clue entre autres, l'affichage continu de l'électrocardiogramme, la mesure de l'oxygène inspiréc et la pression de ventilation afin de documenter le pouls, la tension artérielle, la circulation périphérique, et une respiration adéquate. Des progrès technologiques plus récents tels que la capnographie et l'oxymétrie de surface sont recommandés mais non encore considérés comme mandatoires. Même si la conduite professionnelle selon ces directives est celle qui apparaît raisonnable, pratique et facilement disponible, on admet que celle-ci représente un minimum pouvant être dépassé librement si la situation l'exige.

Pourquoi donc publier un tel document? Il est certain que tous les médecins se sentent d'emblée excessivement gérés avec une liberté de pratique déjà progressivement érodée. La raison la plus plausible de cette publication demeure celle de décrire des normes d'anesthésie dans ce pays contre lesquelles des comparaisons peuvent être faites. Comme individus et comme départements on ne peut être certains qu'on pratique une médecine de qualité qu'en sachant ce qui se fait ailleurs.

Le document publié représente ce qui est couramment pratiqué à travers le pays. Il en détient à chacun d'entre nous de répondre ou d'excéder ce niveau de soins. La satisfaction du patient et sa sécurité doivent être améliorées afin que le pari économique qu'on détient par l'assurance responsabilité soit gagné. Il n'y a aucune intention cachée de standardiser la spécialité. Ce privilège n'est pas donné à la Société, et il n'est définitivement pas recherché. On exprime cependant un espoir qu'une action positive soit faite afin d'adhérer aux directives pour renforcer le respect accordé à notre spécialité

La publication des directives pour les soins médicaux n'est pas sans précédent. Les pédiatres ont adhéré depuis des années à des directives par un programme d'immunisation, les obstétriciens au principe d'allaitement, alors que les chirurgiens adhèrent rigoureusement aux normes de prévention de l'infection. Suite à des désastres, 1'opinion publique a dramatisé la nécessité afin que les anesthésistes incluent certaines mesures de sécurité dans leur pratique. Ceci fut souvent renforcé par des décrets du Coroner ou des Collèges provinciaux des Médecins et Chirurgiens.

Aux Etats-Unis au moins une compagnie d'assurance? (Mutual Insurance Company of Arizona) a imposé un déductible $\$ 25,000$ ainsi que le refus de renouvellement de la police d'assurance si l'anesthésiste est jugé négligent en s'abstenant d'utiliser un ECG, un stéthoscope précordial et une surveillance de la tension artérielle. Le groupe Harvard des hôpitaux universitaires a récemment publié ${ }^{3}$ ce qu'il considère le minimum concernant la surveillance lors de l'anesthésie. Sans aucun doute ceci sera considéré comme la référence concernant les normes de pratique dans ce pays et ce malgré certaines 